\title{
ビス(ニトロメチル)ベンゼン類のアルカリ加水分解
}

\author{
(1977 年 6 月 21 日 受理)
}

千葉耕司・佐藤英悦・小林敏子*

\begin{abstract}
ビス(ニトロメチル)ベンゼン類の $\mathrm{NaOH}$ 溶液によるアルカリ加水分解について検討した。o-圆換体 の加水分解は容易飞進行してフタル酸ナトリウムを好収率で生じたが, $m-$ - p-監換体およびフェニルニ トロメタンは加水分解されなかった。の-置換体を室温下に $\mathrm{NaOH}$ 溶液で処理するときはフタル酸ナト

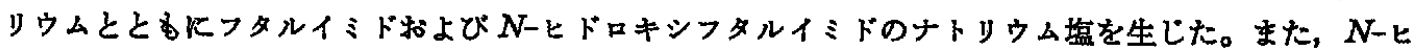
ドロキシフタルイミドはフタルイミドより容易にアルカリ加水分解された。

これらの結果から，の-置換体の反応活性はベンゼン環上で篻接している二つのニトロメチル基の相互 作用に起因しているるのと思われ，反応性主として $N$-ヒドロキシフタルイミドを経て進行するるのと 思われる。
\end{abstract}

\section{1 楮曹}

こトロフルカンを湍鉱酸で加熱処理すると加水分解されてカル

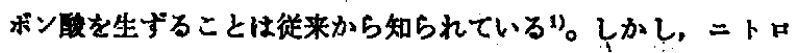
フルカンはフルカリ水溶液中ではニトロン酸塩となって安定化す るすのと考えられており，事实ニトロフルカンのアルカリ加水分 解次ついての報告は悬あたらない。

ところが，著者らは，ききにつぎのような特鱼な反応俳を見い だした2。すなわら（ペンタメチルフェニル）トロメタンおよ び 1,2,3,5-テトラメキル-4,6-ビス(ニトロメナル)ベンゼンは通 常のニトロフルカンと同様にアルカリ加水分解を受けないが, 1,2,3,4-テトラメチル-5,6-ビス（二トロメチル）ベンゼンは容易

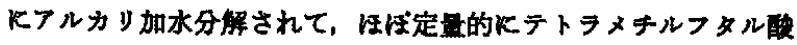
を生じた。

1,2,3,4-テトラメ*ル-5, 6-ビス(二トロメチル)ベンゼンのよ ラK, こつのニトロメチル基をオルト位にすつ化合物だけがアル カリ加水分解されてカルポン酸へ移行するるのとすれば，合成反 応の組み合わせをデザィンするさいの有力な手段を提供できるる のと考えられる。

本埌では，このことを確かめるためにベンゼン㶾に二つのニト ロメチル基だけをるったビス(ニトロメチル)ベンゼン類，および 一つのニトロメキル基をるつフェニルニトロメタンを $\mathrm{NaOH}$ 溶 波ととるに加温し，その反応性を比校検郡した。

\section{2 实跧および結果}

\section{1 试菲および原料}

2.1 .1 具化ベンジル, ジクロロメタンおよび 1,2-ジク ロロエタンは和光純薬社製の特級試薬を，まだンゼン，エーテ ル,メタノールおよびン゙タノールは市敗の一級品を燕留して使用

* 山形大学工学部応用化学科, 992 米沢市城南

1) S. B. Lippincott, Ind. Eng. Chem., 31, 118(1939).

2) K. Chiba, E. Endo et al., Bull. Chem. Soc. Jpn., 49, 2614 (1976).
した。ただし、エーテルは必要に虑じささらに金属ナトリウムで 脱水して使用した。石油エーテルは日本石油社製の試薬を蒸留 し, 30.0 60. $0^{\circ} \mathrm{C}$ の留分を使用した。その他のるのは市敢の一 級試薬をそのま主使用した。

2.1.2 ビス(ニトロメチル)ヘンぜン類およびフェニルニトロ

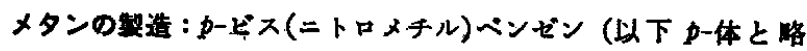

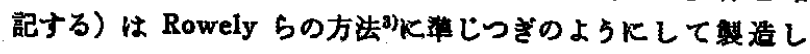
た。

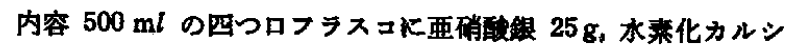
ウム $1 \mathrm{~g}$ お゙よびジク口ロタン $30 \mathrm{ml}$ を入れ, 内容物をはげし くかきまぜながら カービス(ブロモメチル)ベンゼン $13 \mathrm{~g}$ のシク 口ロメタン $(150 \mathrm{ml})$ 溶液を 3 時間かけて滴下し, さらに $0^{\circ} \mathrm{C} て ゙$ 24 時間かきさぜた。なお，この間, 光をし中断するように注意し た。反応混合渡を沪遇し, 沪液から溶剂を留去して暗赤色の粘ち 由ら物を得た。これを、あらかじめー10〜ー5ำに冷却しておい た港硫酸 $20 \mathrm{ml}$ に投し，さらに 1 時睛かきまぜてから砕来 $1 \mathrm{~kg}$ に注ぎ生じた粗製の $p$-ビス(ニトロメチル)ベンゼンを河取した。 十分水洗，乾嬠後，ジクロロメタンついでニタノールから再結 晶した。

○ービス(ニトロメチル)ベンゼン（以下 O-体と咯記ずる）お び $m$-ビス(ニトロメチル)ベンゼン（以下 $m$-体と略記する）は, それぞれ ○ービス(ブロモメキル)ベンゼンおよび m-ビス(ブロモ

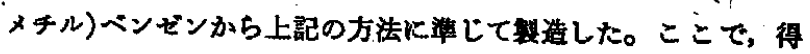
られた 0-体および m-体のそれぞれを過マンガン酸カリウム溶 液で酸化し，塩酸で酸性化して生した沈殿を，さらKニタノール から再結晶したものの IR スペクトルは, それぞれフタル酸およ びインフタル酸に一致した。ビス(ニトロメナル)ベンゼン類の収 率および物性值を表 1に示した。

また、フェニルニトロメタン（以下モノ体と略祀する）は Ko-

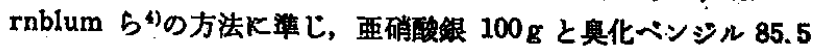
g とを，し中光下K $0^{\circ} \mathrm{C} て 30$ 時間かきまぜた。不溶物を沪別

3) G. L. Rowely et al., J. Chem. Eng. Data, 14, .507(1969).

4) N. Kornblum et ak, J. Am. Chem. Soc., 77, 6269(1955). 
Table 1 Yields and physical constants of bis(nitromethy1)benzenes

\begin{tabular}{|c|c|c|c|c|c|c|c|c|}
\hline \multirow{2}{*}{ Compound } & \multirow{2}{*}{$\begin{array}{c}\text { Yield } \\
(\%)\end{array}$} & \multirow{2}{*}{\multicolumn{2}{|c|}{$\begin{array}{c}\operatorname{mp}\left({ }^{\circ} \mathrm{C}\right) \\
\text { Appearance }\end{array}$}} & \multirow{2}{*}{$\operatorname{IR}(\mathrm{KBr})\left(\mathrm{cm}^{-1}\right)$} & \multirow{2}{*}{$\begin{array}{c}\text { NMR } \\
\text { ppm in CDCls } \\
(90 \mathrm{MHz})\end{array}$} & \multicolumn{3}{|c|}{$\begin{array}{l}\text { Found }(\%) \\
\text { (Calcd.) }\end{array}$} \\
\hline & & & & & & $\mathrm{C}_{(48.98)}^{\mathrm{C}}$ & $\underset{(4.11)}{H}$ & $(14.28)$ \\
\hline$p$-Isomer & 15.2 & $\left\{\begin{array}{l}\text { (lit. } \\
\text { Light }\end{array}\right.$ & $\begin{array}{l}128.5 \sim 130.0 \\
\left.128.0 \sim 130.0^{\text {ay }}\right) \\
\text { Yellow Needles }\end{array}$ & $\begin{array}{rr}1552, & 1431 \\
1378, & 1318 \\
803, & 689\end{array}$ & $\begin{array}{l}5.43\left(\mathrm{~s}, 4 \mathrm{H},-\mathrm{CH}_{2}-\right) \\
7.61(\mathrm{~s}, 4 \mathrm{H}, \mathrm{Ar})\end{array}$ & 48.67 & 3. 97 & 14.36 \\
\hline m-Isomer & 14.2 & Ligh & $\begin{array}{l}111.0 \sim 112.0 \\
\text { Brown Needles }\end{array}$ & $\begin{array}{rr}1554, & 1434 \\
1382, & 1324 \\
784, & 712\end{array}$ & $\begin{array}{l}5.55\left(\mathrm{~s}, 4 \mathrm{H},-\mathrm{CH}_{2}-\right) \\
7.65(\mathrm{~s}, 4 \mathrm{H}, \mathrm{Ar})\end{array}$ & 48.81 & 3.96 & 14. 30 \\
\hline o-Isomer & 6.7 & Light & $\begin{array}{l}80.5 \sim 81.5 \\
\text { Yellow Needles }\end{array}$ & $\begin{array}{rr}1556, & 1458 \\
1380, & 1316 \\
764, & 702\end{array}$ & $\begin{array}{l}5.72\left(\mathrm{~s}, 4 \mathrm{H},-\mathrm{CH}_{2}-\right) \\
7.61(\mathrm{~s}, 4 \mathrm{H}, \mathrm{Ar})\end{array}$ & 48.73 & 4.03 & 14.35 \\
\hline
\end{tabular}

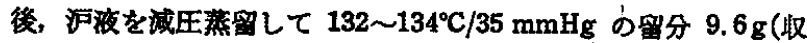
率 14.1\%)を分取した。

2.2 0-ビス(ニトロメチル)ベンゼンの NaOH 溶浓による加 水分席

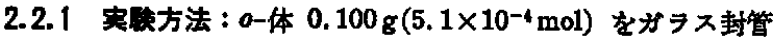
中 $5 \% \mathrm{NaOH} 15 \mathrm{ml}$ とともに所定温度飞加熱した。なお，あら

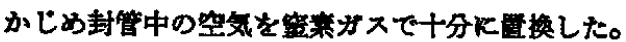

加熱終了後，空温まて冾却し，硝酸銀 $5 \mathrm{~g}$ を水 $5 \mathrm{ml}$ 火溶か几 て加え，湯浴上で 2 時間加温した。放冷後，生成した銀塩を伍

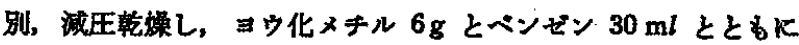
晹浴上て 6 時間透游した。不溶物を沪別し，汇液から溶媒を留去 して反応生成物をメチル化物として取り出した。

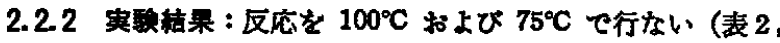
Expt. No. 1，2)，得られる反応生成物（メチル化物）をガスク ロマトグラフィーで分析した結果，注洋一ビークを示し、フタ ル酸シメチルK一致した。ガスクロマトグラフィーの条件はつぎ のとおりである。

カラム: Silicone grease SE-30 10\%/Chromosorb W(80〜100 メ シ $\mathrm{ml} / \mathrm{min}$, 検出器 : FID

また,このるのの IR スベクトルはフタル酸ジメチルに一致 し，その収事は 91\% 火達した。

反応を室温で行なった湯合（表 2, Expt. No.3，4）火得られ たメチル化物の IR スペクトルるフタル酸ジチルに一致した。

しかし，この场合のメチル化物を同棣の条件でガスクロトグ ラフィーで分析した結果，フタル酸シメチルの大きなビーク（ビ 一クII：保持時間 15 分）の汪かに，ごく小さい二つのピーク（ピ 一ク I：保持時間 14 分，ビーク：保持時間 21 分）を認めた。 别に， O-体 $0.5 \mathrm{~g}$ を $1 \% \mathrm{NaOH} 50 \mathrm{ml}$ ととるに室温下で 5 分ふ りまぜたのち同様に処理して得られたネキル化物 $0.35 \mathrm{~g}$ 火つい

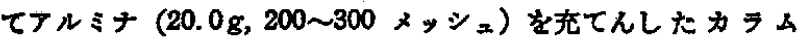
$(1 \times 22 \mathrm{~cm})$ を使用して溶出クロマトグラフィーを行なった。石 油エーテルを溶出耀として使用し，各フラクションから溶媒を留

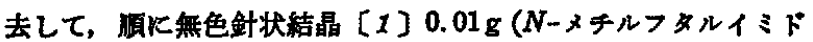
として 2\%), 無色油状物 [2]0.25 g(フタル酸シメキルとして 50\%)，および敏黄色針状結晶 [3] $0.02 \mathrm{~g}(N-$ メトキフタル1 ミドとて 4\%) を得た。[1]，〔2]特よび〔3]の IR スペク トルは，それぞれ别途长造した $N$-メナルフタルイミドフタ ル酸シメチル、および $N$-メトキシフタルイミドル一致した。こ
Table 2 Hydrolysis of o-bis (nitromethyl)benzene in aqueous sodium hydroxide

o-bis (nitromethyl) benzene $: 0.100 \mathrm{~g}, 5 \% \mathrm{NaOH}: 15 \mathrm{ml}$

\begin{tabular}{|c|c|c|c|}
\hline \multirow{2}{*}{$\begin{array}{l}\text { Expt. } \\
\text { No. }\end{array}$} & \multicolumn{2}{|c|}{ Conditions } & \multirow{2}{*}{$\begin{array}{c}\text { Product } \\
\text { (Dimethyl phthalate } \\
(\text { mol } \%)\end{array}$} \\
\hline & Temp. $\left({ }^{\circ} \mathrm{C}\right)$ & Time (min) & \\
\hline 1 & 100 & 300 & 88 \\
\hline 2 & 75 & 40 & 91 \\
\hline 3 & room temp. & 10 & $67^{c)}$ \\
\hline $4^{b)}$ & room temp. & 10 & $56^{6)}$ \\
\hline
\end{tabular}

a) The products were methylated by warming their salts in methyl iodide.

b) $1 \% \mathrm{NaOH} 15 \mathrm{ml}$ was used.

c) The product was contaminated with small amounts of phthalimide and $N$-hydroxyphthalimide.

こで同定試料として使用した $N$-メキルフタルイミドおよび $\mathrm{A}$ メトキシフタルイミドは, フタルイミドおよび $N$ ーヒドロキシフ タルイミドのそれぞれを封管中ジフゾメタンのエーテル溶液と加 温して製造した。なお，このようにして分離した[1]，〔2]拧 よび〔3]についてガスクロマトグラフィーを行なったところ,

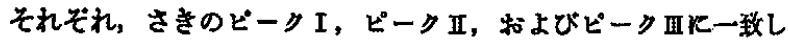
た。

以上の実䍄結果から，0-体は $5 \% \mathrm{NaOH}$ て容易に加本分解さ れてフタル酸ナトリウムを生ずるものと琶められた。また，反応 を堂温で行なった埸合には, 少量のフタルイミドおよび $N$-ヒド ロキシフタルイミドを副生することを認めた。

なお，o-体 $0.100 \mathrm{~g}$ を $5 \% \mathrm{NaOH} 15 \mathrm{ml}$ とともに空温下で 10 分ふりまぜたのち，醀酸を加えて酸性化したところ，微黄色沈股 $0.027 \mathrm{~g}$ を得, このものの IR スペクトルは ○体にほ注一致し た（○-体として 27\%)。このことから，反応を室温で行なった場 合には多量の未反応 0-体があると認められるが，反応生成物を メチル化物として取り出すような，さきの处理法では末反応物を 捕集することができなかったのであろう。

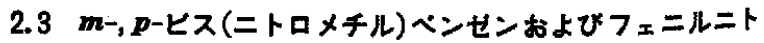
ロメタンと NaOH 溶浓の反忠

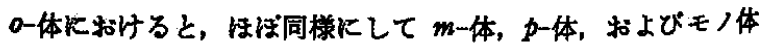
それぞれを 5\% NaOH とともに $100^{\circ} \mathrm{C}$ で5時間加熱処理した。

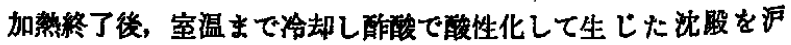
别，乾燥した。この沈股の虽点および IR スペクトルは，それぞ れ $m$-体, p-体, およびフェニルニトロメタンに一致し，大部分 
Table 3 Reaction of $m$-, $p$-bis(nitromethyl)benzene, and phenylnitromethane with aqueous sodium hydroxide Nitro compd.: $0.100 \mathrm{~g}, 5 \% \mathrm{NaOH} ; 15 \mathrm{ml}$, Conditions : $100^{\circ} \mathrm{C}, 5 \mathrm{hr}$

\begin{tabular}{|c|c|c|c|c|}
\hline Expt. No. & Nitro compd. & Recovery of Nitro compd. & Product & \\
\hline 1 & m-Bis(nitromethyl)benzene & 87 & - & \\
\hline 2 & $p$-Bis (nitromethyl) benzene & 94 & - & \\
\hline 3 & Phenylnitromethane & 80 & Methyl benzoate ${ }^{a)}$ & trace \\
\hline $4^{b)}$ & $m$-Bis (nitrometyl) benzene & 85 & Dimethyl isophthalate $\left.{ }^{a}\right)$ & trace \\
\hline
\end{tabular}

a) Methyl benzoate or dimethyl isophthalate was detected by GLC after the product was methylated.

b) $20 \% \mathrm{NaOH} 15 \mathrm{ml}$ was used.

が末反応のまま回収された（表 3)。ただしファニルニトロメ タンを使用したときは反応泥合液を酸性化したのち米反応フェニ ルニトロメタンをエーテルで抽出した。さらに，方体について は20\% NaOH を使用して実験したが，ほぼ同粎の実駼結果に終 った（表 3，Expt. No.4)。

なお，モノ体を，別飞 $5 \% \mathrm{NaOH}$ とともと $100^{\circ} \mathrm{C} て ゙ 5$ 時間加 熱したのち，反応漉合液をの-体におけると同粎にしてメキル化 してガスクァマトグラフィーKかけたところ，安息香酸メチルに 一致するピーク忙こく小さなるのであった。さらに，20\% $\mathrm{NaOH}$ を使用した同様の実験を $m$-体について武みだが，イソフタル酸

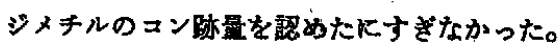

以上の結果から，m-体，p-体，およびモノ体は $\mathrm{NaOH}$ 溶液で 加水分解されがたいるのと認められた。

2.4 フタルイミドおよび $N$-ヒドロキシフタルイミトの Na. OH 溶液による相水分解

0-体を $\mathrm{NaOH}$ 溶液で室温下で処理するときは多量のフタル酸 とともに少量のフタルイミ゙お゙よび $N$-ヒドャキシフタルィミド を生じたことから、フタルイミド扎よび $N$-ヒドャキシフタルイ ミドそれぞれを $\mathrm{NaOH}$ 溶液で処理し，その反灾性を調べた。

$N$ ーヒドロキシフタルイミド $0.100 \mathrm{~g}$ を $5 \% \mathrm{NaOH} 15 \mathrm{ml}$ とと もに封管中で室温下によりまぜた。 30 分後, 硝酸銀 $5 \mathrm{~g}$ を水 $5 \mathrm{ml}$ K溶かして加え, 一夜放愿した。生成した銀塩を減压乾嬠 し，○一体に将るる同様にしてのウ化メテルでメチル化し油状物 $0.104 \mathrm{~g}$ を得た（フタル酸ジキルとして $87 \%$ ）。GLC の保持 時間および IR スペクトルはフタル酸ジメキルに一致した。

つぎに, フタルイミト $0.100 \mathrm{~g}$ を $5 \% \mathrm{NaOH} 15 \mathrm{ml}$ ととすに 室温で 30 分ふりませた。得られた溶液を同侎にして処理しメチ
ル化物として無色針状結晶 $0.09 \mathrm{~g}$ を得た（ $N-$ メルフタルイミ ドとして 84\%)。メタノールから再絬晶したるのの艘点（133〜 $\left.134^{\circ} \mathrm{C}\right)$ および IR スペクトルは $N$ ーメキルフタルイミドー致 した。

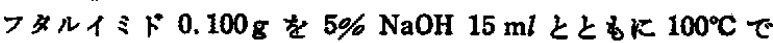

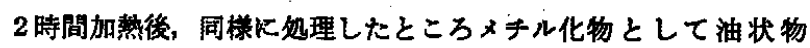
$0.11 \mathrm{~g}$ を得た（フタル酸ジメチとして $85 \%) 。$ GLC の保持時 間和よび IR スベクトルはフタル酸ジメチルに一教した。

以上の結榡から，N-ヒドロキシフタルイミトは $5 \% \mathrm{NaOH} て ゙$ 室温下でる容易飞加水分解されてフタル酸を生ずるが, フタルイ ミドは加熱すれば加水分解されるが空温では加办分解されがたい ことを認めた。

\section{3 考腺}

ニトロフルカン頼はフルカリホ溶湤にニトロン酸塩として溶解 乙安定化するすのと考えられており, 事実, 本報の籍囲です $m-$ 体，p-体，キ上びモノ体は $\mathrm{NaOH}$ 溶液と加鶖しても大部分は未 変化のまま回收された。ところが，のービス(ニトロメナル)ベンゼ ンは肴 $\mathrm{NaOH}$ 溶液で容易に加水分解されてフタル酸を生じた。 このことは，さき著者らが得た实験結果2)，すなわち $1,2,3,4-$ テトラメテル-5,6-どス(ニトロメナル)ベンゼン性着 $\mathrm{NaOH}$ 溶液 で容易に加水分解されるが，1，2,3，5-テトラメチル-4,6-ビス(二 トロメチル)ベンゼンおよび(ペンタメチルフェニル)ニトロメタ ンはフルカリ加水分解されなかった事実に類似するところから， この種の加水分解はオルト位に二つのニトロメチル基をるつ化合 物に特有のすのであろう。

既報2)炕いては副生成物としてテトラメチルフタルイミト，
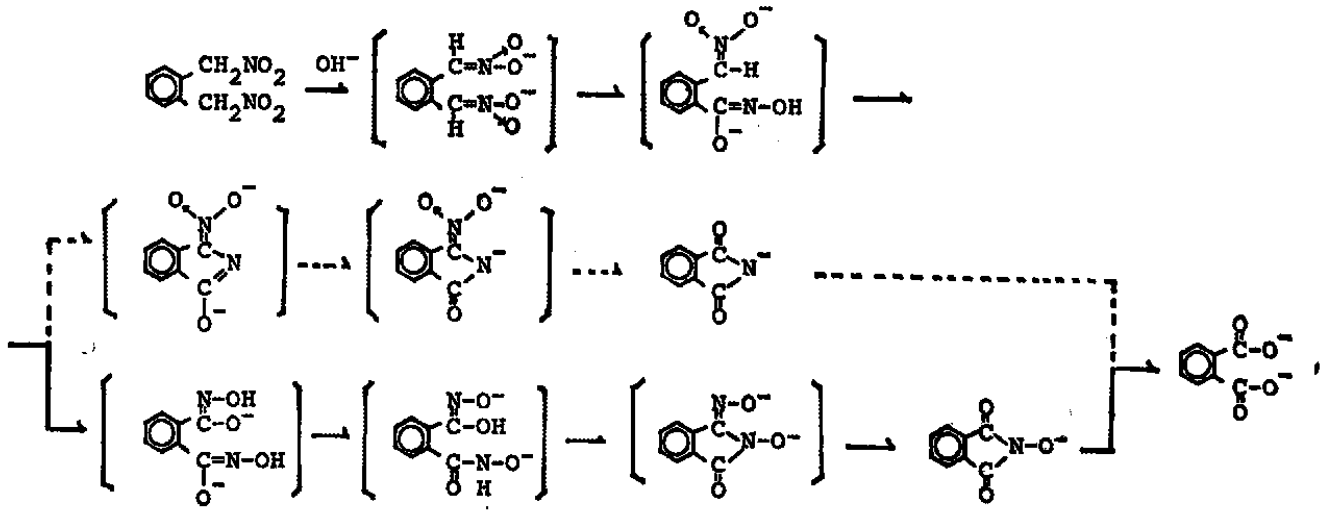

Scheme 1 
N-ヒドロキシテトラメチルフタルイミド, 阽よび 2-ヒドロキシー 3ーヒドロキシイミノ 4, 5, 6,7-テトラメチル-1-イソインドリノン を倹出したことなどから，1,2,3,4-テトラメテル-5,6-ビス(二ト ロメチル)ベンゼンのアルカり加本分解はテトラメチルフタルイ ミドを経てフタル酸を生ずる径路と，N-ヒドロキシテトラメチ ルフタルイミドを経る径路とがあるすのと推察した。本報におい てる，初期反応生成物から少量のフタルイミドおよび $N$-ヒドロ キシフタルイミドとを検出したことから，類例した反经路をた どるるのと思われるが，N-ヒドロキシフタルイミドは室温でる きわめて容易飞てルカリ加水分解されるので，反沈は $N$-ヒドロ
キシフタルィミドを経て進行するよらな径路が立となるものと推 察される（図式 1)。

なお，既報2)では 1,2,3４-テトラメチル-5,6-ビス(ニトロメキ ル)ベンゼンだけがフルカリ加水分解されるのは、ベンゼン珢上 の四つのメキル基の立体障害により隣接する二つのニトトメキル 䔄の相互作用が促進されて五買謤を形成しやすいためであろらと 推察した。しかし、メチル基をるたない。一体が容易にフルカリ 加水分解された事实から四つのメキル基の存在はかならずしす必 要でないことが明らかとなった。

\section{Alkaline Hydrolyses of Bis(nitromethyl)benzenes \\ Koji Chiba, Eietsu Sato and Toshiko Kobayashi \\ Department of applied Chemistry, Faculty of Engineering, Yamagata University; Yonezawa-shi 992 Japan}

The alkaline hydrolyses of bis(nitromethyl)benzenes with aqueous sodium hydroxide were studied. The hydrolysis of the o-isomer at elevated temperatures proceeded smoothly to afford disodium phthalate in a good yield. However, $m$ - and $p$-isomers as well as phenylnitromethan were not hydrolyzed. At room temperaure, the treatment of the $o$-isomer with aqueous sodium hydroxide produced the sodium salt of phthalimide and $N$-hydroxyphthalimide in addition to the sodium salt of phthalic acid. $N$-Hydroxyphthalimide was hydrolyzed more easily than phthalimide in aqueous alkaline media. These results summarized in Tables 2 and 3 suggest that the high reactivity of the o-isomer arises from the interaction of the two adjacent nitromethyl groups on the benzene ring and the main intermediate is $N$-hydroxyphthalimide. 